\title{
PALATAL OBTURATOR PROSTHESIS: A CLINICAL CASE REPORT
}

\author{
Palatal Obtüratör Protezi: Bir Klinik Olgu Sunumu
}

Husniyati ROSLAN, Sa'adiah SHAHABUDIN

$\begin{array}{ll}\text { Makale Kodu/Article Code } & : 340121 \\ \text { Makale Gönderilme Tarihi } & : 27.09 .2017 \\ \text { Kabul Tarihi } & : 04.12 .2017\end{array}$ ABSTRACT

This clinical report describes the details of a prosthodontic rehabilitation of an elderly patient who was diagnosed with mucoepidermoid carcinoma. The palatal defect has caused problems in phonetics and mastication. A previous obturator was made using conventional Polymethyl methacrylate (PMMA). This obturator has caused some discomfort due to food impaction and irritation of the fitting surface over the tissue defect areas. This had resulted in frequent erythema of the areas. Therefore, a new palatal obturator was made still using PMMA but with an addition of an indirect soft acrylic resin over the defect areas. The soft acrylic resin serves to reduce painful irritation of the obturator over the soft tissues around the defect areas. The review appointments up to 6 months revealed satisfactory results with no deterioration in the prosthesis. However, upon the followup appointment at 9 months, we could see some black stains on the fitting surface where the indirect soft acrylic resin was placed. Swabs were taken from the black area on the obturator and the related mucosa intraorally. The swabs were sent for a culture and sensitivity test to find microorganisms that caused the staining. The result confirmed that there were no microorganisms at both areas. This condition suggested that stain could occur on the surface of soft acrylic resin despite good oral hygiene practised by the patient. Further reviews will be made to monitor the condition.

Keywords: Obturator, mucoepidermoid carcinoma, maxillary defect, prosthesis, clinical report.

\section{ÖZ}

Bu klinik olguda, mukoepidermoid karsinom tanısı konan yaşlı bir hastanın protez rehabilitasyonunun detayları açıklanmaktadır. Palatal defekt, konuşma ve çiğneme sorunlarına neden olmuştur. Önceki bir obtüratör, geleneksel polimetil metakrilat (PMMA) kullanılarak yapılmıştı. Bu obtüratör, gıda retansiyonu ve doku yüzey alanlarının üzerinde doldurucu yüzeyinin tahriş olmasına bağlı olarak bazı rahatsızlıklara neden olmuştur. Bu, bölgelerin sik s1k eritemine neden olmuştur. Bu nedenle, yeni bir palatal obturatör hala PMMA kullanılarak yapıld1, ancak farklı olarak defekt alanları üzerinde dolaylı bir yumuşak akrilik rezin ilave edildi. Yumuşak akrilik rezin, obturatörün, defekt alanlarının etrafındaki yumuşak dokular üzerindeki ağrılı tahrişini azaltmaya yarar. 6 aya kadar olan gözden geçirme randevuları, protezde bozulma olmaksızın tatmin edici sonuçlar verdi. Ancak, takip randevusunda 9 ay sonra, dolaylı yumuşak akrilik reçinenin yerleştirildiği montaj yüzeyinde bazı siyah lekeler görüldü. Swablar, obtüratör üzerindeki siyah alandan ve ilgili mukozadan intraoral olarak alındı. Swablar, lekelenmeye neden olan mikroorganizmaları bulmak için bir kültür ve duyarlılık testine gönderildi. Sonuç, her iki bölgede de hiçbir mikroorganizma olmadığını doğruladı. Bu durum, hastanın uyguladığı oral hijyene rağmen yumuşak akrilik rezinin yüzeyinde leke oluşabileceğini düşündürdü. Durumu izlemek için daha fazla takip yapılacaktır.

Anahtar kelime: Obtüratör, mukoepidermoid karsinom, üst çene defekt, protez, klinik olgu 


\section{INTRODUCTION}

The most common type of all intraoral defects is present the maxillary arch which is an opening into the antrum and nasopharynx. ${ }^{1}$ The defects can be divided into congenital malformations or acquired defects. The acquired defects usually result from surgery for oral neoplasms. Post-surgical maxillary defects can cause speech problem, fluid leakage into the nasal cavity and masticatory impairment. ${ }^{1}$

The aim of prosthetic rehabilitation for total or hemimaxillectomy patients is to separate the oral and nasal cavities. Previously, obturators were used to close congenital defects rather than the acquired defects. The functions of an obturator are to close the defect resulted after surgery ${ }^{2}$, restore mastication, improve speech, deglutition and aesthetics of the patients. ${ }^{1}$ Its comfort and stability are associated with the remaining anatomical structures left after the surgery, its design and the material used to construct the obturator.

Mucoepidermoid carcinoma is the most common malignant salivary gland tumour composed of many cells, including mucusproducing, squamous or epidermoid and intermediate type. ${ }^{3}$

This case report demonstrates the combination of Polymethyl methacrylate (PMMA) with soft heat curing acrylic resin to construct an obturator in a patient with mucoepidermoid carcinoma.

\section{CASE REPORT}

A Malay female patient aged 63 years old, had been diagnosed with mucoepidermoid carcinoma 2 years ago and had undergone multiple surgeries, followed by radiotherapy treatment. She was referred to the Prosthodontic Specialist Clinic, Advanced Medical and Dental Institute, Universiti Sains Malaysia, for the improvement of the previous obturator. The patient had been using an obturator for about 4 months when she was first seen at our department. Upon consultation, the patient complained of having some discomfort due to food impaction and irritation of the fitting surface over the tissue defect areas. This had caused frequent erythema of the areas. The previous obturator was made of Polymethyl methacrylate (PMMA).

Intraorally, the soft palate defects extended from posterior of the hard palate up to the posterior extent of the soft palate with bilateral fistula into both nasal cavities (Figure 1).

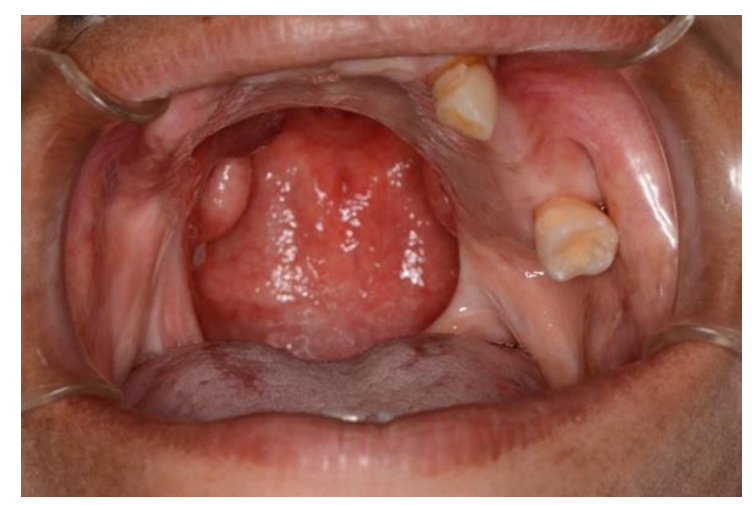

Figure 1. Intraoral view of the large palatal defect in the patient's mouth after the removal of mucoepidermoid carcinoma.

Reddish areas were spotted on the soft tissues overlying the defect areas. There were only two teeth present on the maxilla; the left canine and left second molar. Both of the teeth have some gingival recession and are filled with filling materials, but they are still periodontally strong. Their preservation could add to a better retention of the obturator. Based on the discussion with the patient, it was decided to construct a new obturator with an addition of an indirect soft acrylic resin. The patient was fully informed about the treatment and written consent was taken prior to treatment procedures.

The primary impression was taken using an irreversible hydrocolloid impression material (Alginplus Tropical, Italy) using a perforated stock tray. However, due to the extended defect up to the throat, it was difficult to get the impression material to flow to the intended areas. Therefore, a copy of the previous obturator was made using the silicone putty (Zetaplus, Zhermack, Italy) (Figure 2). 




Figure 2. The copy procedure of the previous obturator using silicone putty.

Impressions were poured using type IV dental stone (William Dental Hard Stone, Malaysia). A special tray was then fabricated using coldcure acrylic resin (Megadenta, Germany) (Figure 3). Secondary impression was taken using monophase polyether impression material (3M ${ }^{\mathrm{TM}} \mathrm{ESPE}^{\mathrm{TM}}$, Germany).

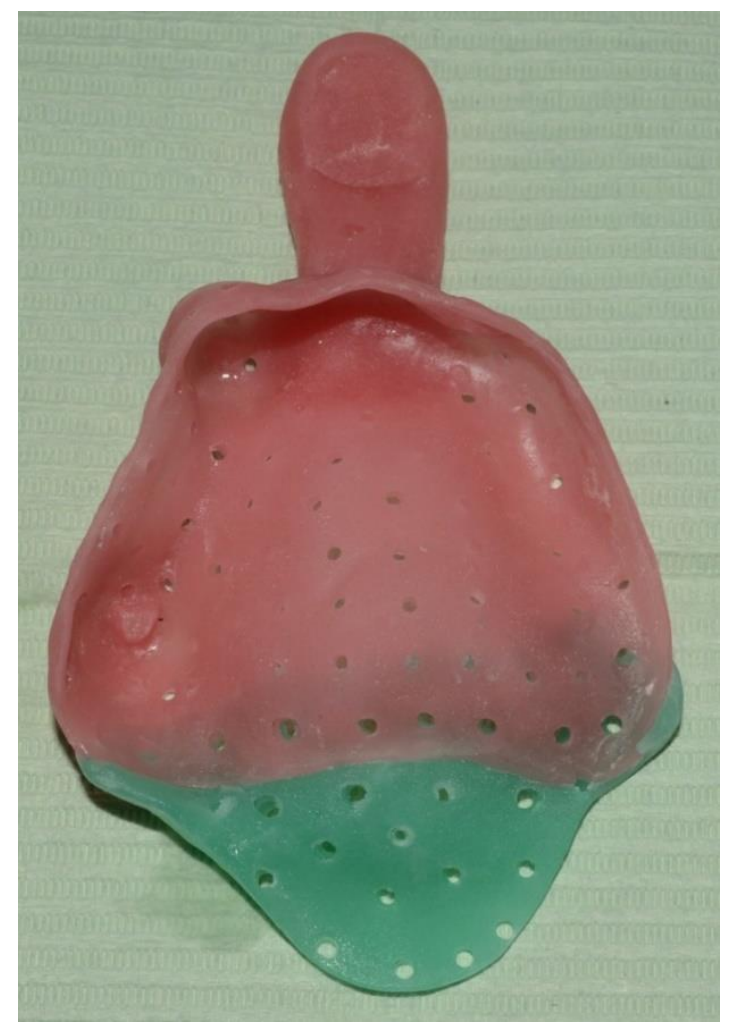

Figure 3. The special tray constructed for the secondary impression.

Bite rim block was then constructed on the master model. Centric jaw relation record was obtained and the master models were mounted on a semi-adjustable articulator (Medesy, Italy). Next, acrylic denture teeth (Dentracryl, Dentsply, Brazil) were arranged as shown in Figure 4. The prosthesis was later tried in the patient's mouth to verify the occlusion, aesthetic appearance and support for the underlying tissues.

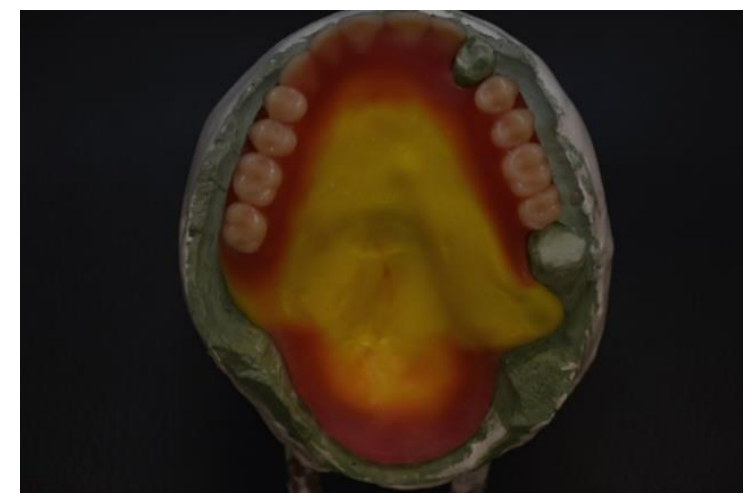

Figure 4. The acrylic denture teeth set-up for try in stage.

Figure 5 shows the flasking stage of the obturator. A layer of wax was placed on the defect area on the model to act as a spacer as shown in Figure 6.

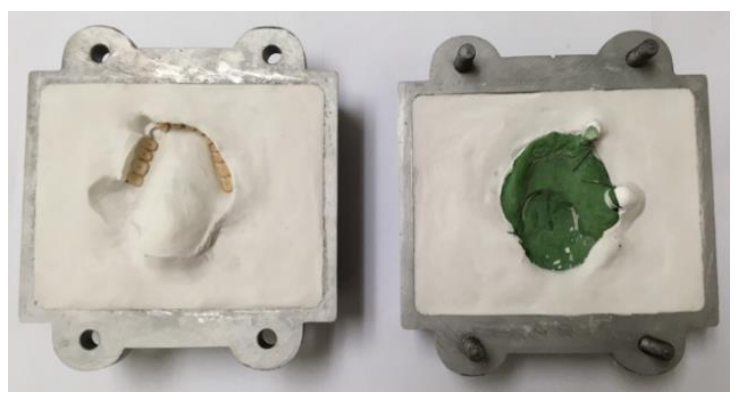

Figure 5. The flasking stage of the obturator.

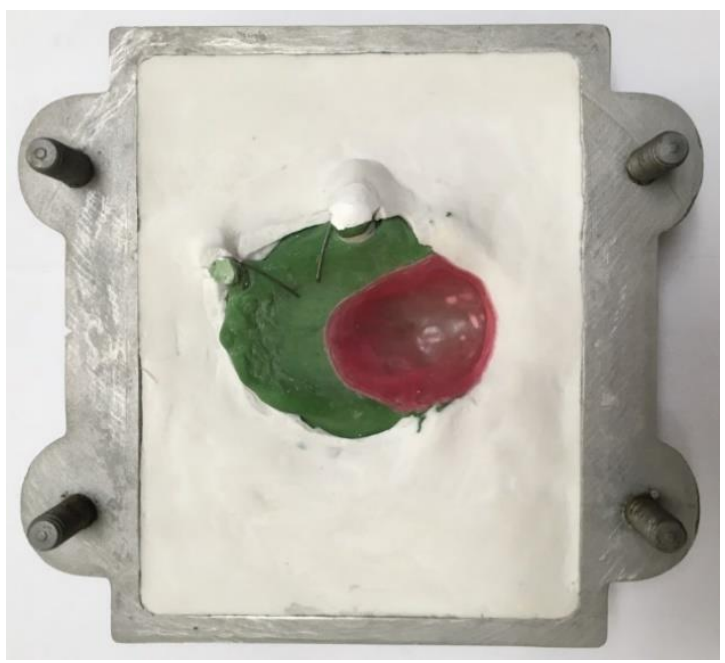

Figure 6. A layer of modelling wax added to the model to give space for the soft reline material later. 
During the final process, soft heat curing acrylic resin (Vertex, Netherland) was added about 1 to $2 \mathrm{~mm}$ thickness on top of the PMMA to cover the defect areas. Trial pack technique was used to pack the PMMA dough. A separating sheet was placed on the dough to facilitate the flask opening. Then the wax was removed and the remaining space was filled with soft heat curing acrylic resin. Finally, it was trimmed and polished in the usual manner (Figure 7).

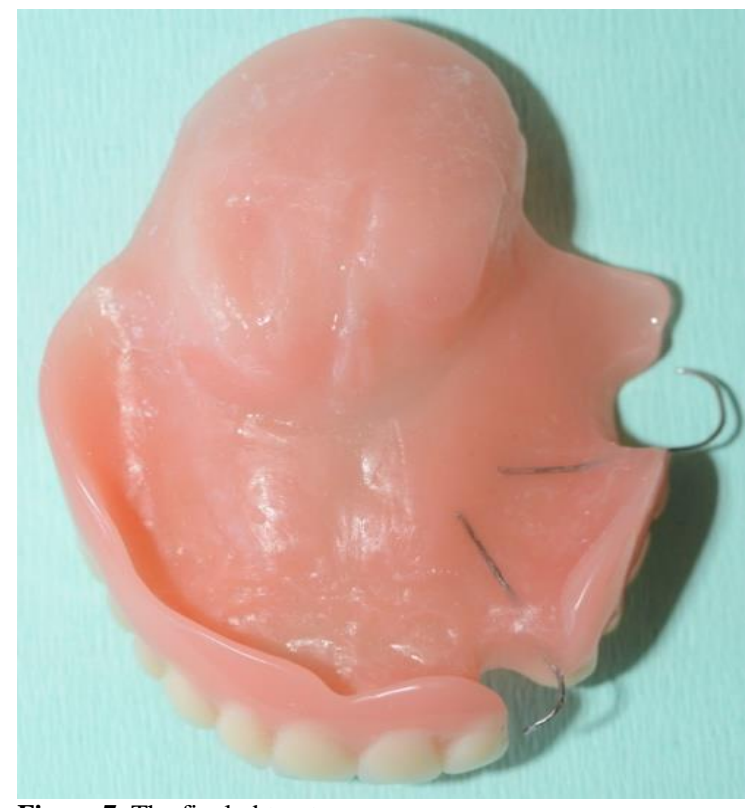

Figure 7. The final obturator.

At the insertion visit (Figure 8), pressure indicating paste was used to check for pressure area. Finally, the patient was given postinsertion instructions in the care and use of the obturator.

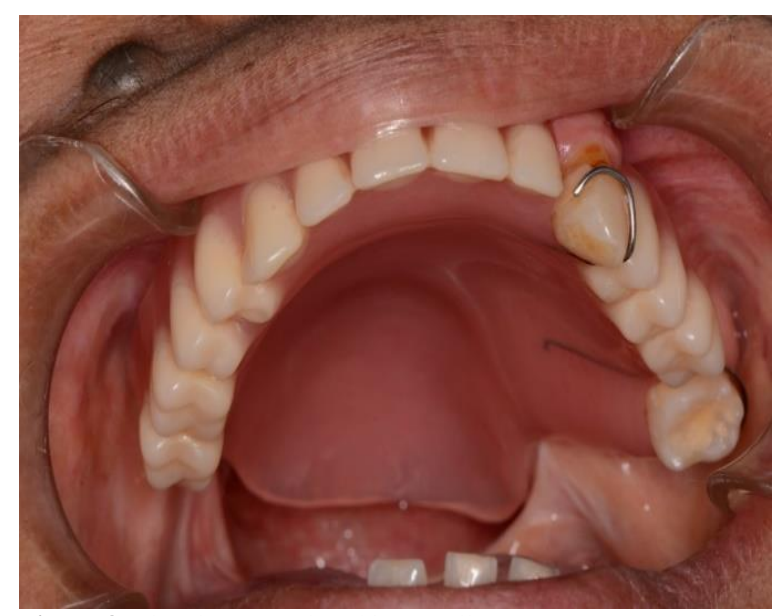

Figure 8. The obturator placed intraorally.
The patient was reviewed a week after the insertion appointment. Small adjustments were made at the posterior side of the obturator where it was impinging on the soft tissues. In the review appointments after a month, 3 months and 6 months, the patient had no further complaint. She was feeling more comfortable in using the new obturator. The obturator was functioning well and was in good condition. Overall, the patient was satisfied with the results of the prosthesis.

However, upon the follow-up appointment at 9 months, we could see some black stains on the fitting surface where the indirect soft acrylic resin was placed (Figure 9).

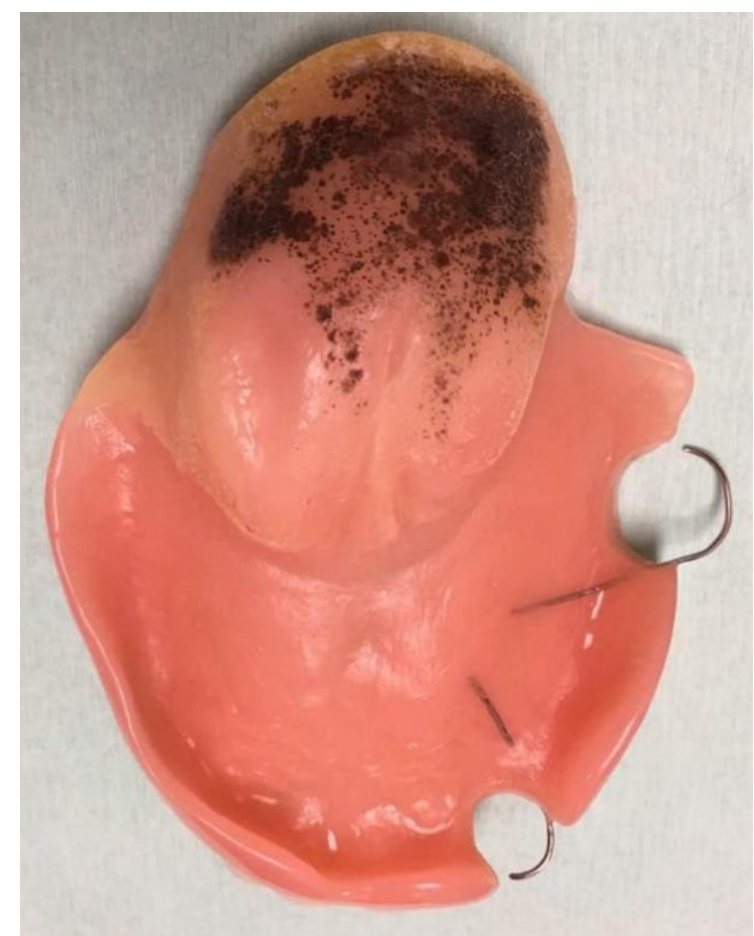

Figure 9. Some black stain present where the soft acrylic resin was placed on the obturator.

The mucosa at the defect areas appeared normal. Therefore, swabs were taken from the black area on the obturator and the related mucosa intraorally. The black stain on the obturator was gently removed using fine polishing bur. The swabs were sent for a culture and sensitivity test to find microorganisms that caused the staining. The result confirmed that there were no microorganisms at both areas. The patient was told about the laboratory result and was 
advised to use a denture cleanser. The stain will be further review in three months to monitor the condition.

\section{DISCUSSION}

In constructing an obturator, many factors have to be taken into consideration in order to restore the function, aesthetic and give comfort to the patient. It requires innovation and creativity of the operator to design the most appropriate obturator that customise to the patient accordingly. This is because different oral cancer patients present with different challenging defect. Obturators made of allPMMA are harder and less stable within the defect area. ${ }^{4}$ In this case report, the obturator was constructed from a combination of an indirect soft heat curing acrylic resin and PMMA. The soft heat curing resin was used to line only the fitting surface of the defect areas where the irritations usually occurred. Due to its soft nature, the soft heat curing resin could engage in some retentive undercuts and its cushioning effect would also absorb some of the masticatory force that acts on the tissue in the defect area. ${ }^{4}$ The combination of these materials can alleviate the irritation compared to using the PMMA solely. Other material such as flexible acrylic, and titanium are expensive while allsilicone obturator is heavy and easily porous. ${ }^{4}$

Another option of restoring the defect would be an obturator supported by dental implants. However, this patient comes from a lower socioeconomic background where she could not afford to pay for the total cost. She also has some travelling problem to come for the review visits at our clinic as she does not have a solid income per month. Considering the economic factor of the patient, that was why we decided to construct the new obturator by using a combination of an indirect soft heat curing acrylic resin and PMMA. The patient was totally satisfied with the obturator as she can function better now.

The previous obturator which was made fully in PMMA did not have any staining on the fitting surface. With the current obturator, some black staining was present on the fitting surface where the soft heat curing acrylic resin was placed. Even though the patient practised good oral hygiene, the black stain still appears. We hope that with the use of denture cleanser, it will help to remove the stain from the obturator.

Overall, the quality of life of the patients with maxillary defects can be improved with the provision of a properly designed obturator. Besides, these patients can also continue their social life in the normal way.

\section{CONCLUSION}

To gain a good prognosis, sufficient retention of the prosthesis is essential. Besides, the prosthesis should be comfortable to the supporting and surrounding tissues that have undergone surgery. Therefore, the material used to construct the prosthesis should be softer and comfortable to these tissues. A better understanding of the needs of the patients would enable the successful rehabilitation of such patients.

\section{ACKNOWLEDGEMENT}

This study has not been supported by any funding. The study was performed at the Prosthodontic Clinic, Advanced Medical and Dental Institute, Universiti Sains Malaysia. The contribution of the team from the Prosthodontics Technology Laboratory, Advanced Medical and Dental Institute, Universiti Sains Malaysia, is highly appreciated. The authors declare that there is no conflict of interest.

\section{REFERENCES}

1. Keyf, F. Obturator prostheses for hemimaxillectomy patients. J Oral Rehabil 2001; 28;821-829.

2. Gay WD and King GE. Applying basic prosthodontic principles in the dentulous maxillectomy patient. J Prosthet Dent 1980;43(4):433-435. 
3. Phasha $\mathrm{Z}$ and Sharma K. Mucoepidermoid carcinoma of palate mimicking vascular lesion: A case report. J Dent Sci Res 2013;4:9-12.

4. Ikusika, OF, Dosumu OO, Ajayi DM, Ogunrinde TJ. Effect of resilient lining of obturator bulbs on patients with maxillectomies. J Prosthet Dent 2016;116(6):932-936. e931

\section{Corresponding Author}

Dr. Husniyati Roslan

BDS, MClinDent in Prosthodontic

Craniofacial and Biomaterial Sciences Cluster

Advanced Medical and Dental Institute,

Universiti Sains Malaysia, Bertam, 13200

Kepala Batas, Penang, Malaysia

E-Mail: husniyati@usm.my

Tel: +6045622247

Fax: +6045622468 